\title{
Development of The Immune System in Very Low Birth Weight (Less than 1500 g) Premature Infants: Concentrations of Plasma Immunoglobulins and Patterns of Infections
}

\author{
MARK BALLOW, K. LYNN CATES, JONELLE C. ROWE, CYNTHIA GOETZ, AND \\ CHARLENE DESBONNET \\ Department of Pediatrics, Divisions of Clinical Immunology [M.B., C.D.], Infectious Diseases [K.L.C.], and \\ Neonatology [J.C.R., C.G.], The University of Connecticut School of Medicine, Farmington, Connecticut 06032
}

\begin{abstract}
Plasma immunoglobulin concentrations of premature infants of birth weight less than $1500 \mathrm{~g}$ were measured longitudinally from birth to 10 months chronological age. Infants were divided into two groups based on gestational age (group I: 25-28 wk; group II: 29-32 wk). In the 1st wk of life, plasma IgG levels correlated with gestational age $(r=0.5, p<0.001)$. At 3 months chronological age, the geometric mean plasma IgG levels were 60 $\mathrm{mg} / \mathrm{dl}$ in group I and $104 \mathrm{mg} / \mathrm{dl}$ in group II infants. Most infants remained hypogammaglobulinemic at 6 months with seven of 11 infants in group I and 13 of 21 infants in group II having plasma IgG levels below $200 \mathrm{mg} / \mathrm{dl}$. In the 1st wk of life, plasma IgM concentrations were 7.6 and 9.1 $\mathrm{mg} / \mathrm{dl}$ in groups I and II, respectively. They rose to 41.8 and 34.7 by 8 to 10 months of life. Plasma IgA concentrations were comparable for groups I and II in the 1 st wk of life (1.2 and $0.6 \mathrm{mg} / \mathrm{dl}$, respectively), but at 1 month of age group I infants had a transient increase in IgA which was not seen in the group II infants $(4.5$ versus $1.9 \mathrm{mg} / \mathrm{dl}$, respectively, $p<0.02$ ). This transient elevation in $\operatorname{IgA}$ did not correlate with type or route of feeding or amounts of transfused blood. Group I and group II infants had comparable rates of infections prior to discharge from the nursery $(p=0.27)$. After discharge, the 43 preterm infants followed until 10 months chronological age had a significantly higher incidence of infections than 41 term infants $(p=0.04)$. In addition, the preterm infants had more lower respiratory infections after discharge than term infants (14 versus $2, p=0.003$ ), and were rehospitalized more often for infection (8 versus $0, p=0.01$ ). Despite severe prolonged hypogammaglobulinemia, none of the preterm infants had bacteremic illness after discharge from the nursery. This study provides normal age-group immunoglobulin values for the first $\mathbf{1 0}$ months of life in very small premature infants. The lack of invasive bacterial infections in this small group of preterm infants after discharge from the nursery suggests that further studies will be necessary to determine whether the hypogammaglobulinemia places these very low birth weight infants at risk for serious infection. (Pediatr Res 20:899-904, 1986)
\end{abstract}

\section{Abbreviations}

VLBW, very low birth weight

NICU, Neonatal Intensive Care Unit

Received December 20, 1985; accepted May 5, 1986.

Correspondence to Dr. Mark Ballow, Department of Pediatrics, University of Connecticut School of Medicine, Farmington, CT 06032.

Supported in part by Grant HD-16481 from the Institute of Child Health and Human Development of the National Institutes of Health.

\author{
IG, immunoglobulin \\ NJ, nasojejunal \\ NG, nasogastric \\ Hct, hematocrit \\ ELISA, enzyme-linked immunosorbant assay
}

During the 3rd trimester of pregnancy, serum IgG levels increase in the fetus by the transfer of maternal IgG across the placenta (1-4). At birth, IgG levels are directly proportional to gestational age $(4,5)$. In a study by Hobbs and Davis (4), nearly all infants 32 wk gestation or less had serum IgG levels below $400 \mathrm{mg} / \mathrm{dl}$ at birth, compared with mean levels of approximately $1000 \mathrm{mg} / \mathrm{dl}$ in term infants (6). It was predicted that, since very small premature infants were born with such low levels of $\operatorname{IgG}$, a large proportion of them could develop marked hypogammaglobulinemia (i.e. less than $100 \mathrm{mg} / \mathrm{dl}$ ) during the first 6 months of life (4), the period when these infants appear to be at the greatest risk of infection (7-9).

Recent advances in perinatal and neonatal care have led to survival rates of up to 60 to $70 \%$ in VLBW infants (i.e. those born weighing less than $1500 \mathrm{~g}$ ), and have resulted in a growing number of these infants in pediatricians' practices $(10,11)$. VLBW infants have more medical problems and higher rehospitalization and mortality rates than term infants $(7,8)$, a result, in part, of an increased incidence and severity of infections (7, $8)$. Although several studies $(4,12)$ have examined the correlation between serum IgG levels and gestational age at birth, none has systematically evaluated IG levels in VLBW infants longitudinally or provided reference values outside of the newborn period. This study was undertaken to describe the ranges of plasma IG levels and the pattern of infection in VLBW infants during the first 10 months of life.

\section{METHODS}

Infants enrolled in the study were appropriate for gestational age and were either inborn or transferred within the first $24 \mathrm{~h}$ of life to the NICU at the University of Connecticut Health Center. All infants had birth weights of less than $1500 \mathrm{~g}$. Informed written consent was obtained from the parents. Infants with major congenital or metabolic defects or intrauterine infection were excluded from the study. Two babies were excluded after doublevolume exchange transfusions. When blood transfusions were required, tightly packed red blood cells (Hct greater than $80 \%$ ) resuspended in saline to Hct $50-60 \%$ were used in order to reduce the amount of IG in the transfusion. Almost all mothers were married, insured, and had 12 or more years of education, 
and fewer than one-fourth smoked. This pattern is consistent with the general newborn population at this institution.

Most infants received hyperalimentation containing $1-2 \mathrm{~g} / \mathrm{kg}$ protein per day (Freamine III, American McGraw, Irvine, CA) prior to initiation of enteral feedings. When clinically stable, infants were fed human milk (supplied by their own mother and supplemented with milk from donor mothers of other premature infants as needed), or formula (Similac PM 60/40, or Similac Special Special Care, Ross Laboratories, Columbus, OH). Infants less than $1200 \mathrm{~g}$ and those who required mechanical ventilation were fed by continuous NJ. The rest were fed by NG. Oral feedings were initiated as tolerated, generally when the infants weighed more than $1500 \mathrm{~g}$.

Seventy-five infants were enrolled in the study. Because the infants reported herein are part of an ongoing study to determine the effects of feeding formula versus human milk on the development of immune system, four infants who developed necrotizing enterocolitis and six who were unable to tolerate enteral feeds by 28 days of life were withdrawn from the study. The remaining 65 infants were followed until discharge from the NICU at a mean of $67 \pm 21$ (SD) days chronological age (range $26-125)$. They were divided into two groups based on gestational age as determined by maternal dates and the method of Dubowitz et al. (13). Group I consisted of 20 infants 25 to 28 wk gestation (mean \pm SD birth weight, $864 \pm 168 \mathrm{~g}$; range $610-1255 \mathrm{gm}$ ) and group II, 45 infants 29 to 32 wk gestation $(1250 \pm 140 \mathrm{~g}, 985-$ $1485 \mathrm{~g}$ ). There were six males and 14 females in group I and 29 males and 16 females in group II. Seventeen infants in group I and 40 in group II were Caucasian, two infants in group I and three infants in group II were black, one each Hispanic, and one in group II was Oriental. There were no deaths in either study group.

Upon discharge from the NICU, infants were seen in the Neonatal Follow-up Clinic at the University of Connecticut Health Center at approximately 4, 6, and 10 months chronological age. Data were collected on infections from 43 infants who were followed for at least the first 10 months of life (14 in group I and 29 in group II).

IG determinations. Immunoglobulin determinations were performed on 60 of the 65 infants. Beginning in the 1st wk of life (median $=$ day 6 ), heparinized blood samples were obtained by heel stick every $2 \mathrm{wk}$ until discharge from the NICU. Thereafter, heparinized blood was obtained by venipuncture at follow-up clinic visits. Plasma was stored at $-70^{\circ} \mathrm{C}$ in small aliquots. Plasma was used instead of serum in this study to allow the recovery of lymphocytes for other studies of the immune system. We have found that IG concentrations in plasma and serum are comparable (Ballowm M, unpublished data). Blood was available for IG measurements in 60 infants for the first 2 months of life, 32 at 6 months, and 22 at 8 to 10 months.

Plasma immunoglobulins $\mathrm{G}, \mathrm{M}$ and $\mathrm{A}$ were measured by an ELISA as previously described (14). The amounts of isotypespecific IG in the plasma sample were determined by comparison with a standard of human serum (Calbiochem-Behring, La Jolla, CA) with known amounts of IgG, IgM, and IgA. Linear regression analysis of the standard curve was performed, and the amount of IG in the plasma was calculated by polynomial regression. The lower limits of the standard curve were $94 \mathrm{ng} /$ $\mathrm{ml}$ for IgG and IgA and $188 \mathrm{ng} / \mathrm{ml}$ for IgM. The interplate/ interday coefficient of variation was $13 \%$. The results obtained by ELISA were comparable to those obtained by nephelometry ( $n=6, r=0.89, p<0.01)$. The ELISA was used in preference to nephelometry because it is a more sensitive assay, and required much smaller volumes of plasma (10-25 $\mu \mathrm{l})$. The values for IgG, $\operatorname{IgA}$, and IgM for each group of infants at various ages were log transformed for statistical analysis and expressed as geometric means. Reference ranges were obtained by taking the antilog of (mean logarithm \pm 2 SD of the logarithms.) Group comparisons were performed by Student's $t$ test on the log transformed values.

Infections. Information about type and number of infections prior to discharge from the NICU was recorded prospectively for all 65 infants by the study nurse. Data were available on the pattern of infections up to 10 months chronological age for 43 preterm infants. After discharge, the mothers of these infants were interviewed by phone and at each clinic visit by the study nurse for information about infections. Interviews were conducted every 2 wk until the infant reached 4 months chronological age, and at monthly intervals thereafter. Because premature infants have different medical problems and are discharged from the hospital later than term infants, it is impossible to have a true "control" group. However, in order to determine the expected incidence of infection in infants in our community at the time of the study, we enrolled 41 healthy term infants as a comparison group. These children were born at the University of Connecticut Health Center during the study period and followed for patterns of infection for 10 months of life. They were comparable to the preterm study infants with regard to maternal marital and insurance status, education, smoking, and race. Mothers of these term infants were interviewed by telephone when the infants were 2 and $4 \mathrm{wk}$ old, and at monthly intervals thereafter. Information was obtained on type and number of infections. Because preterm infants were not discharged from the nursery until 1 to 4 months of age, the incidence of infections in preterm infants after discharge from the nursery was compared to that in term infants by comparing the number of episodes of infections per patient per month of outpatient follow-up until 10 months chronological age.

\section{RESULTS}

IGs. The plasma IgG concentrations of group I infants from 1 wk to 10 months of age are shown in Figure 1 and Table 1 . The plasma levels of IgG in the 1 st wk of life were directly proportional to gestational age $(r=0.5, p<0.001)$. The geometric mean plasma IgG level in the 1st wk of life of group I infants was $251 \mathrm{mg} / \mathrm{dl}$. Thereafter, levels fell progressively, reaching their lowest point $(60 \mathrm{mg} / \mathrm{dl})$ at 3 months chronological age, when 11 of 13 infants had plasma IgG levels less than $100 \mathrm{mg} / \mathrm{dl}$. By 6 months of age, the mean IgG level was $159 \mathrm{mg} / \mathrm{dl}$, and seven of 11 babies still had IgG levels less than $200 \mathrm{mg} / \mathrm{dl}$. At 8 to 10 months, the mean IgG level rose to $273 \mathrm{mg} / \mathrm{dl}$, and three of six infants studied had levels less than $200 \mathrm{mg} / \mathrm{dl}$.

During the 1st wk of life, the geometric mean plasma IgG concentration of the group II infants was significantly higher $(368 \mathrm{mg} / \mathrm{dl}, p<0.002)$ than that of group I infants (Fig. 1 and Table 2). In group II, as in group I infants, mean plasma IgG values were lowest at 3 months chronological age $(104 \mathrm{mg} / \mathrm{dl})$, when eight of 14 infants had plasma IgG levels less than 100 $\mathrm{mg} / \mathrm{dl}$. By 6 months, the mean IgG level was $179 \mathrm{mg} / \mathrm{dl}$, and 13 of 21 infants had levels less than $200 \mathrm{mg} / \mathrm{dl}$. At 8 to 10 months of life, the mean plasma IgG level had risen to $280 \mathrm{mg} / \mathrm{dl}$, and only two of 16 infants had levels less than $200 \mathrm{mg} / \mathrm{dl}$.

As shown in Figure 2 and Tables 1 and 2, the geometric mean plasma IgM concentrations remained comparable $(p>0.05)$ for infants in groups I and II from the $1 \mathrm{st}$ wk of life (7.6 and 9.1 $\mathrm{mg} / \mathrm{dl}$, respectively) until age 8 to 10 months ( 41.8 and $34.7 \mathrm{mg} /$ dl, respectively.)

The plasma IgA concentrations are shown in Figure 3 and Tables 1 and 2 . In group I infants the mean plasma IgA was very low in the $1 \mathrm{st}$ wk of life $(1.2 \mathrm{mg} / \mathrm{dl})$. At 1 and 1.5 months of age the mean plasma IgA rose to 4.5 and $4.3 \mathrm{mg} / \mathrm{dl}$, respectively. At 1.5 months of age, nine of 14 group I infants had elevated plasma levels of $\operatorname{IgA}$ (i.e. $\operatorname{IgA}>3.0 \mathrm{mg} / \mathrm{dl}$ which represents the $99 \%$ confidence limits for geometric mean IgA of group II infants at 1.5 months of age). Paired plasma samples were available on eight of these nine infants. In these paired samples, the plasma IgA had fallen from a mean $( \pm 1 \mathrm{SD})$ of $8.2(4.0-17.1 \mathrm{mg} / \mathrm{dl})$ at 1.5 months to $2.6(1.4-4.8) \mathrm{mg} / \mathrm{dl}$ at 3 months chronological age (paired $t$ test, $p<0.02$ ). In group I infants as a whole, the geometric mean plasma IgA fell to $3.0 \mathrm{mg} / \mathrm{dl}$ at 3 months of age. In an effort to determine the cause of the transient elevation in 


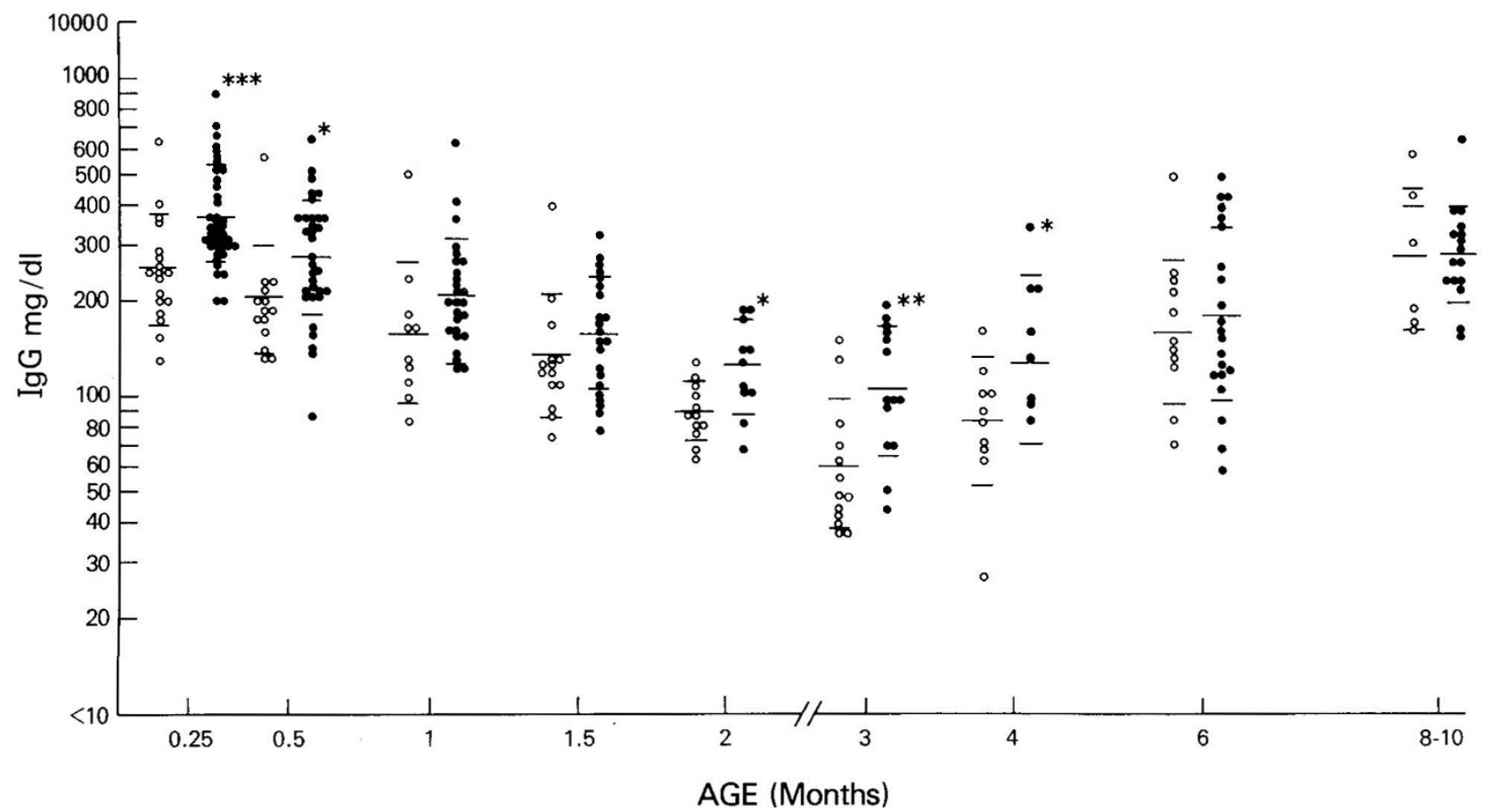

Fig. 1. Plasma IgG concentrations in very small premature infants $(<1500 \mathrm{~g})$ during the first 10 months of life. Open circles are premature infants 25-28 wk gestation (group I), and closed circles are infants 29-32 wk gestation (group II). Bars represent geometric mean \pm 1 SD (*** $p<0.001$, ${ }^{* *} p$ $\left.<0.01,{ }^{*} p<0.05\right)$.

Table 1. Plasma IG concentrations in group I premature infants (25 to 28 wk gestation)

\begin{tabular}{ccccc}
\hline $\begin{array}{c}\text { Age } \\
(\mathrm{mo})\end{array}$ & $n$ & $\begin{array}{c}\mathrm{IgG} \\
(\mathrm{mg} / \mathrm{dl})\end{array}$ & $\begin{array}{c}\mathrm{IgM}^{*} \\
(\mathrm{mg} / \mathrm{dl})\end{array}$ & $\begin{array}{c}\mathrm{IgA} \\
(\mathrm{mg} / \mathrm{dl})\end{array}$ \\
\hline 0.25 & 18 & 251 & 7.6 & 1.2 \\
& & $(114-552) \dagger$ & $(1.3-43.3)$ & $(0.07-20.8)$ \\
0.5 & 14 & 202 & 14.1 & 3.1 \\
& & $(91-446)$ & $(3.5-56.1)$ & $(0.09-10.7)$ \\
1.0 & 10 & 158 & 12.7 & 4.5 \\
& & $(57-437)$ & $(3.0-53.3)$ & $(0.65-30.9)$ \\
1.5 & 14 & 134 & 16.2 & 4.3 \\
& & $(59-307)$ & $(4.4-59.2)$ & $(0.9-20.9)$ \\
2.0 & 12 & 89 & 16.0 & 4.1 \\
& & $(58-136)$ & $(5.3-48.9)$ & $(1.5-11.1)$ \\
3 & 13 & 60 & 13.8 & 3.0 \\
& & $(23-156)$ & $(5.3-36.1)$ & $(0.6-15.6)$ \\
4 & 10 & 82 & 22.2 & 6.8 \\
& & $(32-210)$ & $(11.2-43.9)$ & $(1.0-47.8)$ \\
6 & 11 & 159 & 41.3 & 9.7 \\
& & $(56-455)$ & $(8.3-205)$ & $(3.0-31.2)$ \\
$8-10$ & 6 & 273 & 41.8 & 9.5 \\
& & $(94-794)$ & $(31.1-56.1)$ & $(0.9-98.6)$ \\
\hline
\end{tabular}

* Geometric mean.

$\dagger$ The normal ranges in parentheses were determined by taking the antilog of (mean logarithm $\pm 2 \mathrm{SD}$ of the logarithms).

IgA at 1 to 1.5 months of age, several variables were examined. IgA levels did not correlate with the type (human milk or formula) of feeding $\left(\chi^{2}, p>0.05\right)$, or the amounts of transfused blood these infants had received $(r=0.468, p=0.09)$. Six of the nine infants with elevated $\operatorname{IgA}(>3.0 \mathrm{mg} / \mathrm{dl})$, and two of six infants with low IgA were fed by the NJ route $\left(p>0.05 ; \chi^{2}\right)$.

As was seen in group I infants, the mean plasma IgA concentration in group II infants was very low at birth $(0.6 \mathrm{mg} / \mathrm{dl})$. At 1 and 1.5 months of life, the mean plasma IgA of group II infants was significantly lower than that of group I infants (1.9 versus
Table 2. Plasma IG concentrations in group II premature infants (29 to 32 wk gestation)

\begin{tabular}{|c|c|c|c|c|}
\hline $\begin{array}{l}\text { Age } \\
(\mathrm{mo})\end{array}$ & $n$ & $\begin{array}{c}\mathrm{IgG}^{*} \\
(\mathrm{mg} / \mathrm{dl})\end{array}$ & $\begin{array}{l}\mathrm{IgM}^{*} \\
(\mathrm{mg} / \mathrm{dl})\end{array}$ & $\begin{array}{c}\mathrm{IgA}{ }^{*} \\
(\mathrm{mg} / \mathrm{dl})\end{array}$ \\
\hline 0.25 & 42 & $\begin{array}{c}368 \\
(186-728) \dagger\end{array}$ & $\begin{array}{c}9.1 \\
(2.1-39.4)\end{array}$ & $\begin{array}{c}0.6 \\
(0.04-1.0)\end{array}$ \\
\hline 0.5 & 35 & $\begin{array}{c}275 \\
(119-637)\end{array}$ & $\begin{array}{c}13.9 \\
(4.7-41)\end{array}$ & $\begin{array}{c}0.9 \\
(0.01-7.5)\end{array}$ \\
\hline 1.0 & 26 & $\begin{array}{c}209 \\
(97-452)\end{array}$ & $\begin{array}{c}14.4 \\
(6.3-33)\end{array}$ & $\begin{array}{c}1.9 \\
(0.3-12.0)\end{array}$ \\
\hline 1.5 & 22 & $\begin{array}{c}156 \\
(69-352)\end{array}$ & $\begin{array}{c}15.4 \\
(5.5-43.2)\end{array}$ & $\begin{array}{c}2.2 \\
(0.7-6.5)\end{array}$ \\
\hline 2.0 & 11 & $\begin{array}{c}123 \\
(64-237)\end{array}$ & $\begin{array}{c}15.2 \\
(4.9-46.7)\end{array}$ & $\begin{array}{c}3.0 \\
(1.1-8.3)\end{array}$ \\
\hline 3 & 14 & $\begin{array}{c}104 \\
(41-268)\end{array}$ & $\begin{array}{c}16.3 \\
(7.1-37.2)\end{array}$ & $\begin{array}{c}3.6 \\
(0.8-15.4)\end{array}$ \\
\hline 4 & 21 & $\begin{array}{c}128 \\
(39-425)\end{array}$ & $\begin{array}{c}26.5 \\
(7.7-91.2)\end{array}$ & $\begin{array}{c}9.8 \\
(2.5-39.3)\end{array}$ \\
\hline 6 & 21 & $\begin{array}{c}179 \\
(51-634)\end{array}$ & $\begin{array}{c}29.3 \\
(10.5-81.5)\end{array}$ & $\begin{array}{c}12.3 \\
(2.7-57.1)\end{array}$ \\
\hline $8-10$ & 16 & $\begin{array}{c}280 \\
(140-561)\end{array}$ & $\begin{array}{c}34.7 \\
(17-70.8)\end{array}$ & $\begin{array}{c}20.9 \\
(8.3-53)\end{array}$ \\
\hline
\end{tabular}

* Geometric mean.

$\dagger$ The normal ranges in parentheses were determined by taking the antilog of (mean logarithm \pm 2 SD of the logarithms).

$4.5 \mathrm{mg} / \mathrm{dl}, p<0.02$; and 2.2 versus $4.3 \mathrm{mg} / \mathrm{dl}$, respectively, $p<$ 0.005 ). After 3 months of age the IgA concentration increased steadily in both groups of premature infants, reaching means of $9.5 \mathrm{mg} / \mathrm{dl}$ in group I and $20.9 \mathrm{mg} / \mathrm{dl}$ in group II by 8 to 10 months of life $(p<0.05)$.

\section{INFECTIONS}

Prior to discharge from the NICU, the 65 preterm infants had 59 episodes of infections (Table 3). Seventy percent (14 of 20) of 


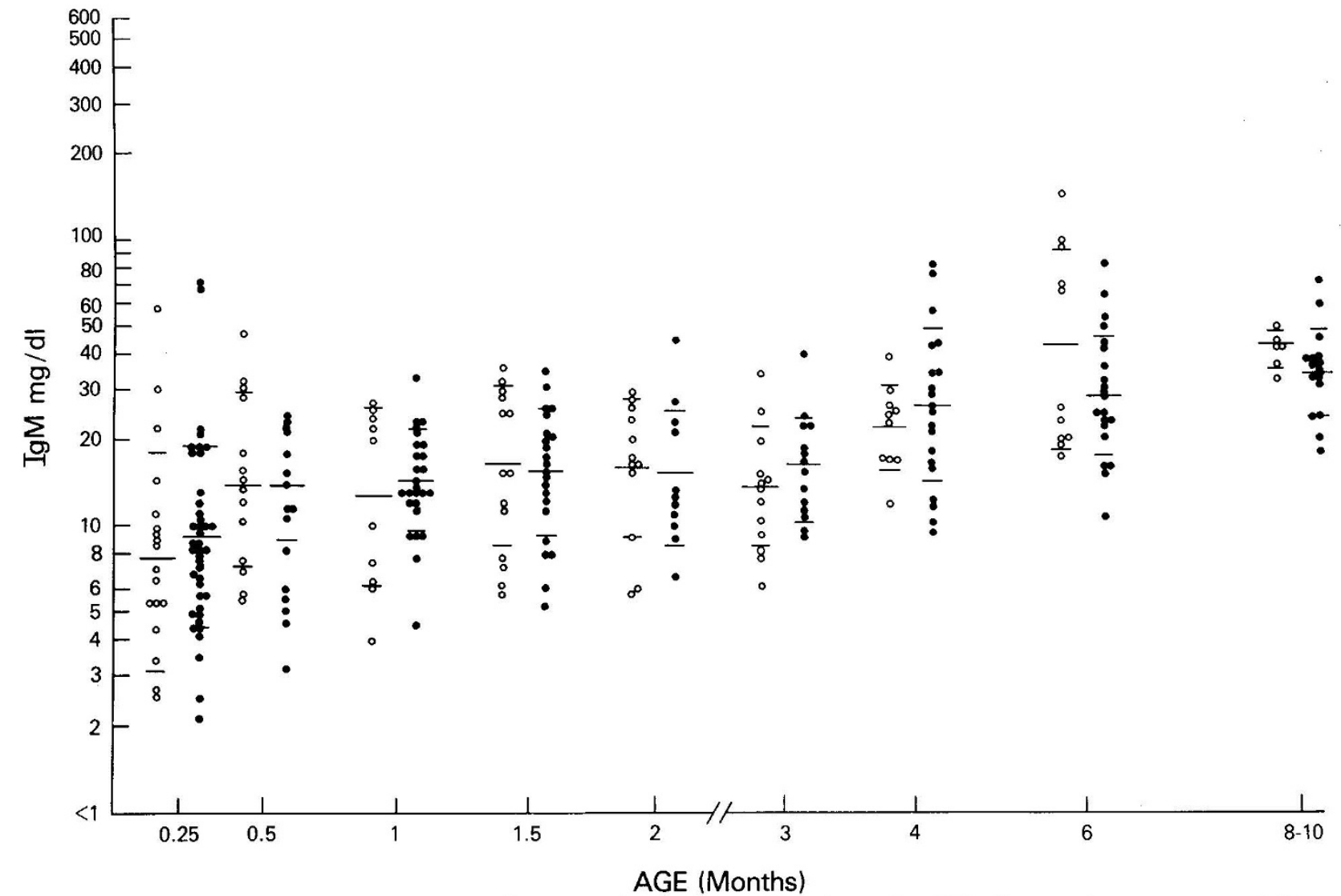

Fig. 2. Plasma IgM levels in very small premature infants $(<1500 \mathrm{~g})$ during the first 10 months of life. Open circles are premature infants $25-28$ wk gestation (group I), and closed circles are infants 29-32 wk gestation (group II). Bars represent geometric mean \pm 1 SD.

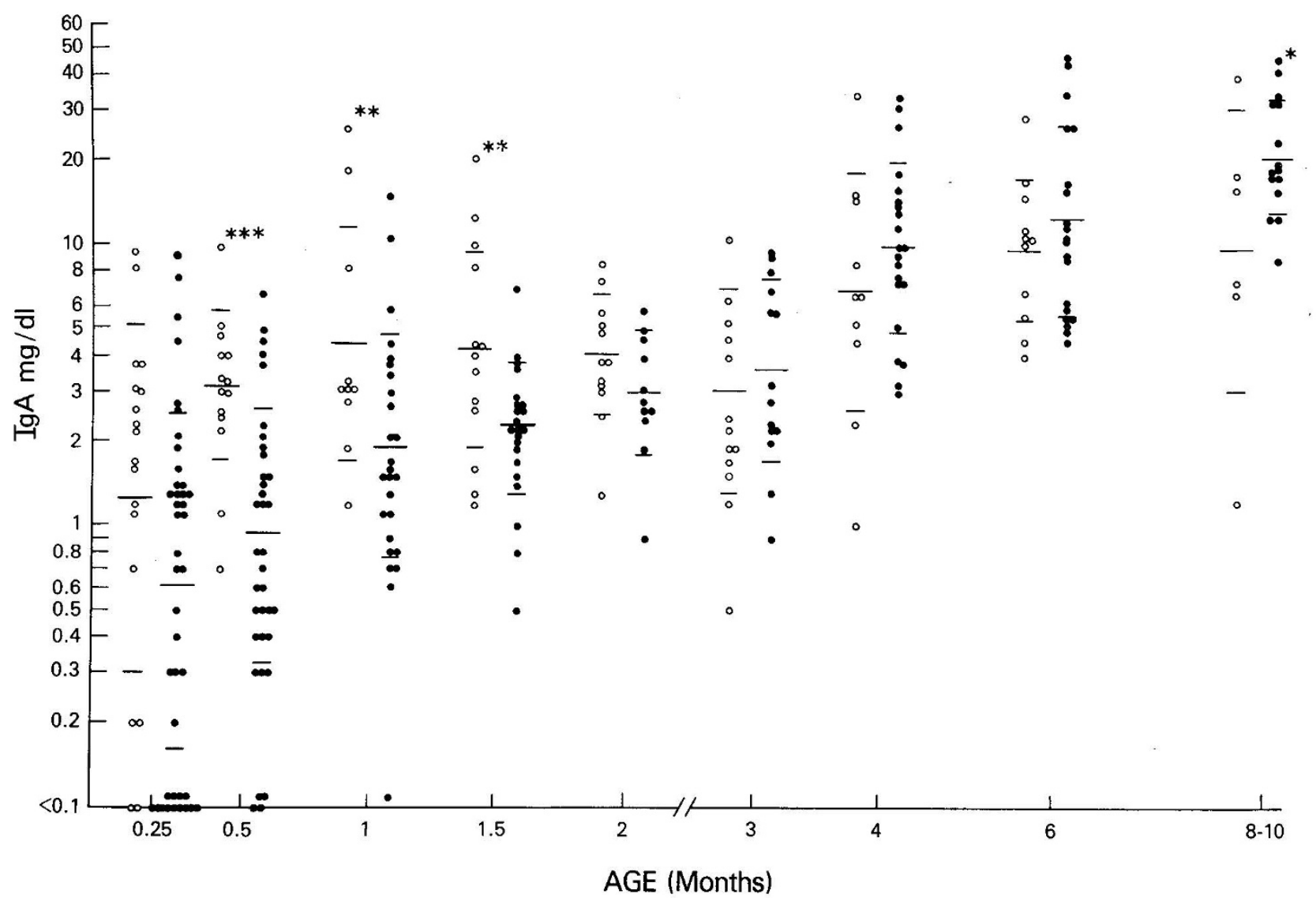

Fig. 3. Plasma IgA levels in very small premature infants $(<1500 \mathrm{~g})$ during the first 10 months of life. Open circles are premature infants $25-28$ wk gestation (group I), and closed circles are infants $29-32$ wk gestation (group II). Bars represent geometric mean \pm 1 SD $\left({ }^{* * *} p<0.001,{ }^{* *} p<\right.$ $\left.0.005,{ }^{*} p<0.05\right)$. 
Table 3. Types of infections in the first 10 months of life

\begin{tabular}{|c|c|c|c|c|c|}
\hline \multirow[b]{2}{*}{ Types of infections } & \multicolumn{2}{|c|}{$\begin{array}{c}\text { Before } \\
\text { discharge }\end{array}$} & \multicolumn{3}{|c|}{$\begin{array}{c}\text { After } \\
\text { discharge }\end{array}$} \\
\hline & $\begin{array}{c}\text { Group } \\
\text { I } \\
(20)^{*}\end{array}$ & $\begin{array}{c}\text { Group } \\
\text { II } \\
(45)\end{array}$ & $\begin{array}{c}\text { Group } \\
\text { I } \\
(14) \\
\end{array}$ & $\begin{array}{c}\text { Group } \\
\text { II } \\
(29) \\
\end{array}$ & $\begin{array}{c}\text { Term } \\
(41)\end{array}$ \\
\hline Upper respiratory & $1 \dagger$ & 0 & 16 & 50 & 83 \\
\hline Otitis media & 0 & 0 & 3 & 16 & 10 \\
\hline Viral syndrome & 1 & 0 & 0 & 1 & 1 \\
\hline Gastroenteritis & 1 & 1 & 5 & 11 & 11 \\
\hline Candidał & 0 & 2 & 5 & 8 & 8 \\
\hline Dermatitis & 8 & 4 & 0 & 1 & 3 \\
\hline Conjunctivitis & 2 & 1 & 2 & 2 & 12 \\
\hline Lower respiratory & 2 & 3 & 3 & 11 & 2 \\
\hline Sepsis & 3 & 3 & 0 & 0 & 0 \\
\hline Probable infection & 11 & 16 & 0 & 0 & 0 \\
\hline Total episodes of infection & 29 & 30 & 34 & 100 & 130 \\
\hline
\end{tabular}

* Number of patients in group.

$\dagger$ Number of episodes.

$\ddagger$ Thrush or Candida diaper dermatitis.

group I infants and $51 \%$ (23 of 45 ) of group II infants had at least one infection prior to discharge. The mean $( \pm 1 \mathrm{SD})$ number of infections per infant per month prior to discharge was $0.53 \pm$ 0.49 for group I and $0.39 \pm 0.49$ for group II $(p=0.27)$. The types of infections encountered are listed in Table 3. Six infants each developed one episode of clinically significant bacteremia between days 3 and 20 of life (median $=11$ ). There was one episode of "probable infection" in each of 27 infants (11 in group I and 16 in group II). Probable infections were defined as episodes associated with clinical deterioration deemed significant enough by the attending neonatologist to continue parenteral antibiotics for longer than $72 \mathrm{~h}$, despite negative bacterial cultures. The policy in the John Dempsey Hospital is to discontinue antibiotics within $72 \mathrm{~h}$ unless infection is strongly suspected. Some of these episodes may have been viral in nature, but viral cultures and serology were not routinely performed. These episodes had no other discernible etiology such as intracranial hemorrhage.

From the time of discharge from the nursery to 10 months chronological age, the 43 preterm infants available for follow-up had 134 infections, compared with 130 in the 41 term infants. Group I had a mean $( \pm 1 \mathrm{SD})$ of $0.36 \pm 0.23$ infections per infant per month after discharge and group II had $0.43 \pm 0.24$. The overall incidence of infections in the preterm infants after discharge from the nursery $(0.40 \pm 0.24$ infections per infant per month) was significantly higher than that in the 41 term infants $(0.32 \pm 0.14, p=0.04)$. As can be seen in Table 3,14 preterm but only two term infants had lower respiratory infections (pneumonia or bronchiolitis) after discharge $(p=0.003)$. In addition, eight of the preterm but none of the term infants were rehospitalized for infections $(p=0.01)$, all of which involved the lower respiratory tract. Three of the rehospitalized infants required admission to an intensive care unit, and two infants required mechanical ventilation for culture-documented respiratory syncytial virus pneumonia. At the time of rehospitalization, these infants had plasma IgG concentrations comparable to the mean of their respective group at that chronological age. None had bronchopulmonary dysplasia and their median duration of oxygen ( 9 days, range $0-21$ ) and ventilator therapy ( 8 days, range $0-49$ ) in the NICU were comparable to those of the other preterm infants (18, range $0-81$; and 6 , range $0-60$ days, respectively).

There was no difference between rates of infection in preterm infants who were fed breast milk and those who were fed formula. Also, there was no correlation between the use of betmethasone prior to delivery and subsequent pattern of infection in the NICU, nor was there a correlation between rate of infection and the number of years of maternal education, however, only three mothers had less than $12 \mathrm{yr}$ of education. Too few mothers smoked to allow analysis for this variable.

\section{DISCUSSION}

Although the number and isotype diversity of surface IG bearing-B lymphocytes are well-developed by $20 \mathrm{wk}$ gestation, normally the fetus synthesizes only negligible amounts of serum or plasma immunoglobulins $(1,2,15)$. In the last trimester of pregnancy, maternal IgG is transferred across the placenta to the fetus $(2,3)$. At birth, full term infants have serum levels of IgG comparable to, or even higher than, maternal levels (2). In contrast, the levels of $\mathrm{IgG}$ in premature infants at birth are directly proportional to gestational age (this study, 4, 12, 16). Since IgM and IgA do not cross the placenta, serum concentrations of these IGs are very low at birth in both term and preterm infants unless the infant has had an intrauterine infection.

Normal reference ranges for plasma or serum IG values for VLBW infants have not been reported beyond the newborn period. Previous studies of serum IG levels in premature infants included larger premature infants ( $>33$ wk gestation) and/or follow-up periods of, at most, only the first few weeks of life (4, 12, 16-19). In this study, we determined normal age-group IgG, IgM, and $\operatorname{IgA}$ values for premature infants less than $32 \mathrm{wk}$ gestation for the first 10 months of life. We demonstrated that the plasma IgG levels fell to remarkably low levels between 2 and 4 months of age, reaching less than $100 \mathrm{mg} / \mathrm{dl}$ in $83 \%$ of group I and $71 \%$ of group II infants. By 10 months of age, the plasma IgG levels were similar in the two groups of premature infants, but still markedly below the mean of $661 \mathrm{mg} / \mathrm{dl}$ reported by Stiehm and Fudenberg $(6)$ as well as others $(20,21)$ for normal full term infants of the same chronological age.

Berg (17) reported that serum IgM levels in premature infants less than 33 wk gestation were low at birth and remained low for the first $3 \mathrm{wk}$ of life. We confirmed this finding and went on to demonstrate that the premature infants' plasma IgM levels increased gradually becoming comparable to those reported for full term infants by 10 months of age $(6,20,21)$.

In most other studies, serum IgA has not been detectable at birth in premature infants. Berg (17) found that the majority of infants still had no demonstrable IgA by $3 \mathrm{wk}$ of age. Even full term infants have been reported to have serum IgA concentrations less than $2 \mathrm{mg} / \mathrm{dl}$ at birth $(3,6,20)$. However, these studies used techniques which are not as sensitive as the ELISA method used in the present study. We detected plasma IgA during the 1 st wk of life in $89 \%$ of infants in group I and $82 \%$ of those in group II. IgA levels remained low until 3 months of age. Thereafter, the plasma IgA increased substantially, perhaps due at least in part to antigenic stimulation in the home, particularly the introduction of new foods $(22,23)$. By 8 to 10 months of age, the plasma IgA concentrations in both groups had risen to approximately the same level as reported for term infants at comparable ages $(6,20,21)$.

Unlike the group II premature infants, group I infants showed a transient rise in plasma IgA at 1 to 1.5 months of age, the etiology of which is unclear. The absence of a similar transient rise of IgA in group II infants suggests a physiological or environmental difference between the two groups. Although group I infants received a larger volume of blood transfusions per $\mathrm{kg}$ birth weight than did group II infants, the blood for transfusion was tightly packed (Hct $>80 \%$ ) and was resuspended in saline to minimize the administration of plasma containing immunoglobulins to these infants. There was no correlation between blood transfusion volume and plasma IgA levels in group I infants. It is possible that the transient increase in plasma IgA seen in group I infants reflects the physiological response of the less mature gut to the initiation of enteral feedings. Our numbers were too small to determine the effects of "feeding problems," and the route (NJ or NG) of feeding on plasma IgA levels. Additional studies will be necessary to elucidate the pathogenesis of these changes in plasma concentrations of $\operatorname{IgA}$ in group I infants. 
Our finding of a higher rate of all infections $(p=0.04)$, lower respiratory tract infections $(p=0.003)$, and rehospitalizations for infections $(p=0.01)$ in preterm than term infants confirms prior studies $(7,8)$. The plasma IgG levels in the eight infants with the most serious infections after discharge from the NICU (i.e. those who were rehospitalized) were comparable to those of their respective groups at that age. The number of infants followed for infections after discharge from the nursery was too small to conclude that there was an increased risk of invasive bacterial disease. Nevertheless, the lack of bacteremic illness in these 43 infants, despite prolonged severe hypogammaglobulinemia, may reflect important differences between this population and patients with congenital or acquired immune deficiency who are unable to produce specific antibody. For example, premature infants unlike most patients with immunodeficiency disorders, can make protective levels of specific antibodies in response to immunization with tetanus and diphtheria toxoids $(24,25)$. Thus, despite the severe hypogammaglobulinemia, premature infants may have humoral immune responses which are adequate to protect against invasive disease from many organisms.

The introduction of intravenous immune serum globulin has made it possible to provide therapy to boost plasma IgG levels in premature infants. The clinical benefits of long-term intramuscular $\gamma$-globulin prophylaxis in premature infants are unclear $(26,27)$. To date, no reports of safety or efficacy on the prophylactic use of intravenous immune serum globulin are available in premature infants. Thus, the routine use of immune serum globulin must await controlled clinical trials to determine both the benefits and adverse effects of such therapy. Although the number of infants followed after discharge were too small to determine the risk of serious invasive bacterial disease, our studies suggest that hypogammaglobulinemia alone may not prove to be an indication for therapy with immune serum globulin.

Acknowledgments. The authors thank Joanne Williams for her expert secretarial assistance.

\section{REFERENCES}

1. Hyvarinen M, Zeltzer $P, O h$ W, Stiehm ER 1973 Influence of gestational age on serum levels of alpha-1 fetoprotein, IgG globulin, and albumin in newborn infants. J Pediatr 82:430-437

2. Kohler PF, Farr RS 1966 Elevation of cord over maternal IgG immunoglobulin: evidence for an active placental IgG transport. Nature 210:1070-1071

3. Gitlin D 1971 Development and metabolism of the immune globulins. In: Kagan BM, Stiehm ER (eds) Immunologic Incompetence. Year Book Medical Publishers, Chicago, pp 3-16
4. Hobbs JR, Davis JA 1967 Serum IgG-globulin levels and gestational age in premature babies. Lancet 1:757-759

5. Papadatos C, Papaevangelou G, Alexiou D, Mendris J 1969 Immunoglobulin levels and gestational age. Biol Neonate 14:365-373

6. Stiehm ER, Fudenberg HH 1966 Serum levels of immune globulins in health and disease: a survey. Pediatrics 37:715-727

7. Douglas JWB, Mogford C 1953 Health of premature children from birth to four years. Br Med J 1:748-754

8. Hack M, DeMonterice D, Merkatz IR, Jones P, Fanaroff AA 1981 Rehospitalization of the very-low-birth-weight infant. A continuum of perinatal and environmental morbidity. Am J Dis Child 135:263-266

9. Cates KL, Rowe JC, Ballow M 1983 The premature infant as a compromised host. Curr Probl Pediatr 13:6-63

10. Peacock WG, Hirata T 1981 Outcome in low-birth-weight infants ( 750 to 1500 g): a report on 164 cases managed at Children's Hospital, San Francisco, California. Am J Obstet Gynecol 140:165-172

11. Kitchen WH, Yu VYH, Orgill AA, Ford G, Rickards A, Astbury J, Lissenden JV, Bajuk B 1983 Collaborative study of very-low-birth weight infants. Am J Dis Child 137:555-559

12. Haworth JC, Norris M, Dilling L 1965 A study of the immunoglobulins in premature infants. Arch Dis Childh 40:243-250

13. Dubowitz LMS, Dubowitz V, Goldberg C 1970 Clinical assessment of gestational age in the newborn infant. J Pediatr 77:1-10

14. Lindsten T, Seeley JK, Ballow M, Sakamoto K, St. Onge S, Yetz J, Aman P, Purtilo DT 1982 Immune deficiency in the x-linked lymphoproliferative syndrome. II. Immunoregulartory T cell defects. J Immunol 129:2536-2540

15. Gathings WE, Lawton AR, Cooper MD 1977 Immunofluorescent studies on the development of pre-B cells, B lymphocytes, and immunoglobulin isotype diversity in humans. Eur $\mathrm{J}$ Immunol 7:804-810

16. Rothberg R 1969 Immunoglobulin and specific antibody synthesis during the first weeks of life of premature infants. J Pediatr 75:391-399

17. Berg T 1968 Immunoglobulin levels in infants with low birth weights. Acta Paediatr Scand 57:369-376

18. Evans HE, Akpata SO, Glass L 1971 Serum immunoglobulin levels in premature and full-term infants. Am J Clin Pathol 56:416-418

19. Yeung CY, Hobbs JR 1968 Serum-gamma G-globulin levels in normal, premature, post-mature and "small-for-dates" newborn babies. Lancet 1:1167-1172

20. Allansmith M, McClellan BH, Butterworth M, Maloney JR 1968 The development of immunoglobulin levels in man. J Pediatr 72:276-290

21. Buckley RH, Dees SC, O'Fallon WM 1968 Serum immunoglobulins: I. Levels in normal children and uncomplicated childhood allergy. Pediatrics 41:600 610

22. Nielson E, Friis CW 1980 Influence of intestinal microflora on the development of the immunoglobulins. Acta Path Microbiol Scand [Sect C] 88:121-126

23. Vonehara K, Tazune S, Hashimoto K, Sasaki S 1985 The effect of antigenic stimuli derived from the diet and microbial flora on immunoglobulin levels. In: Germfree Research: Microflora Control and Its Application to the Biomedical Sciences. Alan R. Liss Inc., New York, pp 351-353

24. Bernbaum JC, Draft a, Anolik R, Samuelson J, Barkin R, Douglas S, Polin R 1985 Response of preterm infants to diptheria-tetanus-pertussis immunizations. J Pediatr 107:184-188

25. Cates KL, Ballow M, Rowe JC, Goetz C 1986 Specific and functional antibody responses in very low birth weight (VLBW) infants. Pediatr Res 20:388A

26. Steen JA 1960 Gamma globulin in preventing infections in premature infants. Arch Pediatr 77:291-294

27. Amer J, Ott E, Ibbott FA, O'Brien D, Kempe CH 1963 The effect of monthly gamma globulin administration on morbidity and mortality from infection in premature infants during the first year of life. Pediatrics 32:4-9 